\title{
Ukraine Open University: Its Prospects in Dis- tance Education Development
}

Bohdan Shunevych

Open International University for Human Development "Ukraine"

\begin{abstract}
The genesis, initiation, and expansion of distance education at the Ukraine Open International University for Human Development, located in Kyiv, will be examined in this case study, starting with a brief look at the positive changes taking place in Ukraine's traditional educational system, as well as recent developments in the country's distance education (DE) system. To help readers understand the University's development from an insider's perspective, societal factors that currently influence its interand extra-institutional environment will also be examined. Next, the history, organizational structure, institutional activities, and background of the Ukraine Open International University for Human Development, along with the reasons driving the University's dual mode activities - both traditional and distance education - will be briefly analyzed. Included in this analysis is a summary of the challenges surrounding the application of both traditional and distance education models.

The author concludes his case study by reflecting upon Ukraine Open International University for Human Development's experiences within the context of its being both a traditional education provider and new dualmode distance education provider. Also discussed are some key indicators and predictions about what the future may hold for the University.
\end{abstract}

\section{Introduction}

The history of distance learning (DL) development in Ukraine can be divided into three stages of innovation: (1) correspondence; (2) mail and television/radio/satellite; and (2) the Internet and the World Wide Web (Matthews, 1999). The first stage was comprised of print-based correspondence courses that have been in use since the late 1920s. The second stage, spanning from the early 1980s to the present, used emerging technologies that combined television, radio and telephone with print. Heralding the arrival of the third stage, Ukraine's higher educational institutions are now introducing Internet and World Wide Web technologies into its educational processes in response to emerging needs of full- and part-time students, as well as for the country's distance learning students. 
Ukraine Open University: Its Prospects in Distance Education Development 2

To help readers understand what is happening in Ukraine today with regards to distance education, this case study will explore the experience of one institution: the Ukraine Open International University for Human Development (Ukrainian abbreviation is VMUROL) and its attempts to position itself in the face of rapid changes underway. The developments described in this case study go beyond mere hybridization of distance with traditional face-to-face forms. Rather, it focuses on the evolution of new forms of learning enabled by new information and communication technology. The University now finds itself planning for future learning environments, situations that encompass both hybridization and increased flexibility in the provision of distance programs.

\section{Higher Education in Ukraine}

To understand the changes occurring at VMUROL, it is important to appreciate the various contexts in which the University operates and from which the drivers for change derive. Since gaining its independence in 1991, Ukraine has been forging ahead to develop its own educational system to match and meet its own needs. In recent years, Ukraine's universities have become pioneers in introducing distance education in this country.

Today, Ukraine's educational system can be divided into the following structures: (1) basic schools; (2) vocational and technical secondary schools; and (3) higher schools that offer four levels of accreditation. As of 1998/99, there were 653 institutions at the first and second levels of accreditation, and 298 institutions at the third and fourth levels of accreditation (institutes, academies, universities). These educational institutions served 503.7 thousand and 1,210.3 million students respectively (Osaulenko,1999).

Since 1991, tremendous and positive changes have taken place in Ukraine's educational system. They are as follows:

- Non-state (private) educational institutions have appeared.

- All state educational institutions have a right to develop their non-state or private sector. (The state only pays for training academically advanced students, while the remainder are financially responsible for their own tuition).

- Institutions have more rights and choices in the organization of their teaching/learning activities.

- A new educational system that coincides with the western one is also being introduced.

Prior to 1991, students studied for five years at the higher schools to become specialists in fields such as engineering, education, and medicine for example,

International Review of Research in Open and Distance Learning 
after which, and depending on their previous academic speciality, they could engage in post-graduate studies to obtain a scientific degree of Kandidate Nauk (Sciences) in technology, medicine, philosophy, or philology. Finally, students could proceed to research and write their doctoral thesis.

Today, Ukraine's universities offer a combination of its previous educational system and the western one: Bachelor's degree (4 years); Master's degree $(+1-2$ years), then Kandidate Nauk ( +3 years); and finally, Doktor ( +3 years). Academics who have obtained the status of Kandidat Nauk can work in Ukraine's educational institutions, where they will likely have the position of Docent; at research institutions they will likely hold the position of senior researcher. Academics who have obtained the status of Doktor may either hold a position of Professor in one the country's educational institutions or a lead researcher at one of its research institutions.

Other positive changes include:

- Students can now study abroad.

- Foreign educational institutions, as well as joint ones, can now work in this country.

- International cooperation in training specialists and compiling educational materials with our foreign partners has increased.

- Introduction of new teaching/learning technologies in Ukraine's educational institutions has moved the educational process from a teachercentered to learner-centered orientation.

- Students have a wider choice in place, time, language, etc., of learning

From an historical perspective, Ukraine has always been well known throughout the world for its fine system of universities. Kyiv Mohyla Academy (1632), the University of L'viv (1661), the University of Kyiv (1834), and the L'viv Polytechnic Academy (1844) were some of first higher educational institutions in Europe and the world. These universities are currently able to meet the demands of Ukrainian society as reflected in student enrolment. However, their ability to enrol students in the future will be limited, due to rapid changes occurring throughout Ukrainian society. To remedy this situation, new education technologies are being introduced in different science and technology programs. As well, new professional programs are being introduced into Ukraine's university system to help address the emerging needs of our country's industrial, agricultural, professional and business sectors. In short, Ukraine's citizens now require training and retraining to meet the growing demands occurring in Ukrainian society. In response, newly founded state and non-state universities, academies, institutes are beginning to appear in Ukraine's cities, with affiliates located in small towns and abroad.

International Review of Research in Open and Distance Learning 
In spite of all the changes currently facing Ukrainian society, government funding for higher education has diminished considerably, requiring public sector educational institution to secure new sources of revenue to fund future growth. As a direct result, the majority of newly founded institutions are not public institutions, but instead non-state or private sector ones, including the subject of this case study, VMUROL.

In comparison to well-known state institutions that use traditional methods of teaching and learning, the newly emerging private sector institutions have more flexibility regarding expenditures to increase their competitive advantage in the Ukrainian education marketplace. One such cost effective measure is the introduction of innovative technologies that support distance-learning initiatives.

However, until the year 2000, there was no legal provision in Ukraine for its education institutions to pursue distance-learning initiatives. This situation changed in the summer of that year with the signing of legislation intended to foster the development of distance education: the "Decree of the President of Ukraine: Measures to Develop the National Component of the Internet Global Information Network and Provide Broad Access to this Network in Ukraine," and the "Order of the Ministry of Education and Science of Ukraine" (Minister order \#293, July 2000). In connection with the creation of the Ukrainian Distance Education Center at the National Technical University in Kyiv, and International University of Finance, the main objective of this legislation was to create a viable system of post-secondary distance educational options throughout the country in accordance with the mandate of the National Program of Information.

In reality, however, distance education had been developing in Ukraine for nearly two decades before this "official legislation" was signed into effect. For example, 1996 saw the first international project (UNESCO/IIP) on distance education, launched by the International Research and Training Center of Information Technologies and Systems (IRTC). Headed by Dr. Olexyi Dovgialo, the Center was founded in 1986 on the basis of research conducted at the Department of Dialogue and Educational Systems at the Hlushkov Cybernetics Institute. As well, the IRTC had been cooperating with UNESCO since being founded in 1986 and was a co-organizer of the second UNESCO Congress "Education and Informatics," held in Moscow, Russia in 1996 (Dovgialo et. al., 1996). On the basis of these developments and of the ongoing work performed at IRTC, the International Center of Distance Education was founded in October 2001.

The Problem Laboratory of Distance Education, headed by professor Volodymyr Kukharenko of the Kharkiv National Technical University, is another well-known distance education research center. Located in the eastern part of Ukraine, the laboratory was founded in 1997, although the basis for the organization of DE at the University was developed in the 1991-1996 time frame. The chief aims of the laboratory are the development of distance courses, software, methodological materials, and to research challenges currently facing distance education. Since 
Ukraine Open University: Its Prospects in Distance Education Development 5

1997, the University has been conducting an online seminar, "Methodological Problems of Distance Education."

The Technology Promotion Center at L'viv Institute of Management (LIM), situated in the western part of Ukraine, is likewise a reputable source of distance education research. LIM is a privately owned higher educational institution that, in spite of its private status, cooperates with many state and non-state institutions in the eastern and western parts of Ukraine, as well as abroad.

Although too numerous to list here, there are several other higher education institutions currently engaged in researching and developing distance education in Ukraine, most notably: Taras Shevchenko National University of Kyiv, Kyiv National University of Trade and Economics, Kharkiv Technical University of Radioelectronics, Lvi'v Polytechnic National University, Donetsk National University, and the Vinnytsia State Technical University.

\section{The Ukraine Open University}

The Ukraine Open International University for Human Development (Ukrainian abbreviation is VMUROL) is the first truly open university of its kind in the country. Registered as a not-for-profit private sector institution in 1998, VMUROL's founders are the Kyiv State Administration, the Ukrainian League of Invalids, the International Centre of Human Development, and various regional state administrations.

VMUROL's main premises are currently housed in a three-story building located in downtown Kyiv. Other buildings currently rented are located in different areas of Kyiv. Recently, the State Administration of Kyiv has allocated an additional 14.5 acres for a new campus, that is currently under construction, and will include several two, three, and five-story buildings totalling 10,000 $\mathrm{m} 2$. It will also include lecture rooms and laboratories that will enable VMUROL to establish and deliver specialized services such as a career centre, rehabilitation centre, library and information centre, engineering laboratories, design laboratory, computer laboratory, social studies centre, and law centre, to name just a few.

The mandate of VMUROL is as follows:

- To provide access to higher technical and humanities education to any person, residing in any region of Ukraine.

- To widen access to higher education, especially for the disabled and for those residing in isolated rural areas.

- To modify examination and study regulations in recognition of people with

International Review of Research in Open and Distance Learning 
Ukraine Open University: Its Prospects in Distance Education Development 6

special needs, especially those with disabilities who must be given equal opportunities to participate.

- To initiate curriculum development and integrate it into the European and world educational community, using new and emerging teaching technologies.

- To integrate people with disabilities into society (especially under market conditions), by providing access to good professional training at the institution oriented at this specific segment of population.

- To conduct preparatory and career guidance courses for entering higher educational establishments.

- To initiate and engage in research.

Currently, VMUROL offers students 31 degree programs in the following fields of study:

- Humanities (Social Work, Psychology, Languages, Publishing and Editing)

- Law

- International Relations (International Law, International Information, International Economics)

- Medicine (Physical Rehabilitation, Medical Engineering)

- Economics and Business (Banking, Accounting and Auditing, Marketing, Trade, Environmental Economics)

- Engineering (Computers, Everyday Electronic Equipment, Catering, Technology of Building Constructions and Materials).

With the mission of serving educational and training needs of Ukrainian people, industry and business on a region-by-region basis, VMUROL affiliates are located in all regions throughout the country. VMUROL also cooperates with the Higher School of Business (Wyzcza Skola Biznesu), in Ostrowiec Swietokrzyskiego, Poland and the University of Applied Sciences in Heidelberg, Germany.

\section{Course Subsystem}

To be a leader in higher education delivery means today's universities must employ the newest teaching and learning technologies to their strategic advantage.

International Review of Research in Open and Distance Learning 
One such technology used in the delivery of distance education is the World Wide Web. However, despite the above listed technological advancements, it is still difficult to find a new distance education model that fully addresses the unique needs of Ukrainian society, primarily because of the current economic climate in the newly independent country. As a result, VMUROL relies heavily on traditional education models and established elements of distance education technology such as audiocassettes, video-films, CD-ROMs, and electronic textbooks, to meet the growing demands of its students. This is especially true for part-time students enrolled at the University and its affiliates.

Nonetheless, top calibre instructors, programmers, and engineers are invited to work at the University, some coming from well-known Kyiv universities. As well, many of VMUROL's faculty come from other regions in Ukraine, as well as other countries. Currently, teams of instructors, programmers, methodologists, psychologists, and course designers are compiling distance courses for all subjects taught for first and second year students specializing in nine of the 31 degree programs mentioned above. It is anticipated that next year many of VMUROL's first-year students studying these nine specialities will enjoy the use of a distance education model that addresses their unique needs as Ukrainians. Distance courses developed in other Ukraine universities and abroad are also being purchased by VMUROL.

Unfortunately, VMUROL does not have much experience compiling distance courses on its own at this time and the underlying standards or criteria for evaluation have yet to be agreed upon. This is why VMUROL is partnering with foreign educational institutions, creating research and design teams whose objective is to compile distance education courseware designed to address the unique needs of Ukraine's citizens and, where applicable, licensing these courses for use at home in Ukraine and in other countries. For example, the author is currently designing a distance course for students studying English at VMUROL, using a textbook entitled: "Getting on in English" (Corness \& Haiduk, 1998) as the basis for its curricula. Produced jointly by VMUROL's faculty of Foreign Languages, the Lviv Polytechnic National University, Ukraine, and the School of International Studies and Law, located in Coventry University, U.K., this text was also funded with the assistance of the European Union-sponsored TempusTacis Joint European Project. The next step in this project is joint compilation of the distance course.

Another important objective for international cooperation is compilation of distance courses for the disabled. Such courses will be planned and compiled in cooperation with partners from the USA, UK, Norway, Netherlands, Poland and other countries that have a wealth of experience to share and transfer. VMUROL is also developing a traditional education model, signalling its intent to be a dual mode university in the near future.

International Review of Research in Open and Distance Learning 
Ukraine Open University: Its Prospects in Distance Education Development 8

\section{Student Subsystem}

VMUROL is open to applicants who have earned their Secondary Education Certificate. The year 1999 saw the first cohort of full-time and part-time students enrolled in a four-year Bachelor's degree program (a one-year Master's program will be offered in the near future). The University does not discriminate on the basis of gender, race, nationality, religion, either in the recruitment of teaching staff or in the admission of students. A written entrance exam takes place during the July - September time frame each year. To gain admission to VMUROL, prospective students must pass rigorous testing in Ukrainian language or literature, Ukrainian history, plus one subject in biology, chemistry, mathematics, or English, depending upon their choice of academic speciality. To date, VMUROL's student body has grown dramatically, and the University has managed to establish a solid reputation with its partners in business, innovative technologies, and engineering.

VMUROL operates on a trimester system, wherein students attend classes from October to December, January to April, and May to July. Currently, the number of full and part-time student enrolees stands at about 11,000, ten percent of whom are considered disabled in areas such as: vision, auditory, spastic, and/or other medical restrictions. Considering that in Kyiv alone the number of disabled students attending university exceeded 35 percent for the academic year 2000 - 2001, VMUROL is clearly making an important contribution to society.

VMUROL deploys several methods of learner assessment and evaluation.

- Modular system of knowledge assessment

- Course projects

- Individual tasks in the form of lab works and essays

- Student's scientific work in the form of writing articles and conference reports

To obtain funding, VMUROL cooperates with various government agencies, universities, international organizations, and individual donors, all of which encourage the application of new educational technologies to help solve social problems. Such donors have been conferred the rank of Honorary Founder of VMUROL. Municipal government grants and Kyiv State Administration also step in to provide grants for disabled and socially unprotected students, whereas the Ukrainian League of Invalids and donors provides grants for students with disabilities in regional affiliates. Other sources funding include payments to students for fees awarded by juridical and physical entities and firms, and grants.

The University's main expenditures include the creation of the material and technical base of the University, provision of educational and methodological

International Review of Research in Open and Distance Learning 
Ukraine Open University: Its Prospects in Distance Education Development 9

processes, staff salary, and study payments of medal-holders and winners of international school contests.

Faced with information overload in the form of new and different subjects, as well as a dearth of textbooks and other educational media to facilitate learning, Ukrainian students are working towards earning their degrees despite these obstacles. One of the purposes of our Distance Education (DE) Center is to help students overcome these obstacles. For example, VMUROL students have access to audiocassette, video, CD-ROM, electronic versions of their lecture courses, textbooks and other materials. These materials are currently the mainstay of our students' library, computer and language laboratories, all of which can be accessed by students who have computers at home or their office.

\section{Regulatory Subsystem}

VMUROL's structure is determined by the President of the University as guided by higher education regulatory requirements of the state. In accordance to Ukrainian education law, VMUROL's President is appointed by the University Council, the University's supreme managing body responsible for the organizational and administrative concerns of VMUROL staff in areas such as workload.

The main structural subdivisions of the VMUROL are:

- Educational and methodological department

- Seven faculties and their departments in Kyiv

- Affiliates in 26 cities and towns throughout Ukraine

- A library, Distance Education Center, Linguistic Center, Monitoring Center and other structures that provide educational activity at the University

Functions of the Scientific and Methodological Council are:

- Determination of the main trends of educational and methodological scientific research work

- Approval of curricula and programs on all subjects at VMUROL

- Recommendations for improving the educational work

- Approval of textbooks, courses, lectures and other educational materials

- Determination of the main content and the structural subdivisions of the University

International Review of Research in Open and Distance Learning 
Ukraine Open University: Its Prospects in Distance Education Development10

- Academic programs

As previously mentioned, courses for all subject areas are developed by course lecturers and instructors; however, prior to gaining acceptance, all courses and programs are discussed and reviewed by the Department Council and confirmed by the Scientific and Methodological Council of the VMUROL. The forms of studying at the University are: full-time studies; part-time studies; correspondence studies; and distance learning (this mode was proposed to students in 2001). VMUROL offers classes leading to the Bachelor degree (4 years) and a Specialist degree (5 years). Both degrees may be earned either on a full-time, part-time, or distance basis.

\section{Logistical Subsystem}

Currently, VMUROL employs about 200 full-time faculty members and about 1,000 part-time and visiting professors. Five people make up the staff at the Distance Education Center. University affiliates also house offices of the Center.

Staff members of the Center and its affiliates are encouraged to participate in different traditional and online training sessions, seminars, and conferences held by both domestic Ukrainian and foreign institutes and universities (Topical Issues, 2000; Topical Issues, 2001; Shunevych B., 2001). VMUROL holds seminars and training sessions for teaching staff that focus on the different problems of DE, such as compiling distance courses.

\section{Technological Subsystem}

Over the past five years, Internet connectivity has grown considerably in Ukraine. Fiber optic cables, Ukrainian "Sich" satellite, radio Ethernet, as well as a combination of other satellites and telephone lines are currently being used. However, there remains an overall lack of modern communication connectivity in Ukrainian cities, small towns, and villages, primarily due to the high cost of telephone and Internet access. Computers are gaining acceptance, similar to what other established technologies such as radio, tape-recorders, and television initially encountered. Despite the costs, the number of computer users has increased considerably and Internet access has expanded across Ukraine during the past five years. Inexpensive or free Internet access may be obtained at all Ukrainian universities, colleges and many high schools; research institutions; IATP centres founded in Ukraine for American program alumni and student research work; and British Council offices located in many Ukrainian cities. Internet access, albeit more expensive, may also be obtained at Internet-cybercafes, computer clubs, and the workplace.

International Review of Research in Open and Distance Learning 
Ukraine Open University: Its Prospects in Distance Education Development11

\section{The Future of Distance Education Development at VMUROL}

At present, VMUROL provides access to traditional modes of teaching using the newest methods of pedagogy such as project methods and case studies. As mentioned earlier, one of the chief aims of the University is to provide education and training based on modern technologies, including distance education. In the near future VMUROL will become a dual-mode (both face-to-face and distance education mode). Its courses and programs will be initiated and expanded for delivery in either traditional or solely distance education formats, as well as a hybrid mixture of both conventional and distance education models.

As with any other educational institution in Ukraine, VMUROL faces chronic funding shortages, especially for development of its own materials and a technical base for its traditional educational model. This is the main reason why VMUROL is working to improve its programs using distance learning technology.

At present, lecturers and instructors employ elements of distance teaching for full- and part-time students. The next step, therefore, will be to compile our own distance courses. Prior to the compilation phase, all the necessary methodological materials will be assembled by VMUROL's Distance Education Centre (Information, 2000; Talanchuk, Shevtsov; Bazhan, Hemba, 2001). All necessary software and hardware will also be predetermined by the Distance Education Center. From time to time, seminars on different problems of distance course compilation and delivery have been prepared by the representatives of VMUROL's Distance Education Centre as well as representatives from other Ukrainian distance education centers.

At this time, it has been determined there is no necessity to adopt DE using so-called "case technology" (Shunevych, 1999). Instead of case technologies, VMUROL has elected to design delivery of distance learning courses using Internet technologies (Shunevych, Kokhan, 2000). On the basis of the research performed by Ukrainian and foreign scientists, new technology will be introduced in the educational process. In Ukraine, such investigations are being conducted in major cities such as Kyiv, Kharkiv and L'viv.

Problems exist concerning communication between the University and its affiliates; these problems also include lack of Internet access for some of our affiliates. As a result, VMUROL is only able to use certain elements of distance learning technology at this time. Nonetheless, VMUROL's DE Center is working to develop electronic versions of self-training courses on mathematics, Ukrainian language and other subject areas for secondary school students wishing to enter the University. This work is being accomplished with help from VMUROL's partners in Ukraine and abroad who have experience using distance learning modes at their institutions: the Higher School of Business (Wyzcza Skola Biz-

International Review of Research in Open and Distance Learning 
Ukraine Open University: Its Prospects in Distance Education Development12

nesu), Ostrowiec Swietokrzyskiego, Poland and the University of Applied Sciences, Heidelberg, Germany are two such partners.

\section{Conclusions}

It is premature to specify what VMUROL's has learned in initiating and expanding its distance education activities. Nevertheless, VMUROL's staff members have learned some important and valuable lessons:

- Initiators/leaders who appreciate the central necessity of these technologies, as well as those who know how to manage distance education at the institution are needed to introduce and expand the newest technology in an educational institution.

- Foreign experience can complement our own methodology in the compilation of educational materials (Shunevych, 2001).

- Cooperation with VMUROL's foreign partners can facilitate compilation of courses and their licensing abroad.

- Large-scale investments are needed prior to introducing the newest technologies.

- Initiation and expansion of distance education must be achieved on the state level. Prior to the year 2000, there were only private sector initiators of DE in our country. But after the above-mentioned President's decree and Ministerial order, state educational institutions began to introduce DE activities.

- It is not uncommon for staff to resist changing their habits to employ new methods of teaching and learning. However, in VMUROL's case, staff members were more commonly initiators of change, principally because they participated in conferences abroad.

- The institution can benefit from inviting experienced instructors, managers, programmers and the like, from other educational institutions and firms to develop distance courses and deliver lectures.

In light of the present economic crisis in Ukraine, along with the related lack of modern communication infrastructures in our cities, small towns and especially our villages, only a few state operated higher education institutions can afford to purchase modern computer technology and access the Internet. In short, due to issues stemming from lack of funding, access, and physical infrastructure, DE courses are not widely used in Ukraine. VMUROL and other private sector higher educational institutions are filling the void and also finding themselves

International Review of Research in Open and Distance Learning 
Ukraine Open University: Its Prospects in Distance Education Development13

flexible enough to capitalize on cost-saving opportunities to introduce and use innovative educational technologies such as the Internet. Distance learning technologies enable private sector institutions to be more competitive compared to many well-known state institutions that use more traditional methods of teaching and learning. Indeed, many people by reason of disability, infirmity, work, or residence, often cannot attend traditional universities; VMUROL is there to fill this void.

Many challenges face VMUROL. For instance, the University requires highly qualified specialists to compile educational materials for use in all majors and professional disciplines. Likewise, knowledgeable tutors are needed to conduct these courses. To remedy this situation, seminars are currently being held for teachers and students to help them to successfully teach and learn using new education technologies. Prominent specialists hailing from both Ukrainian and foreign educational institutions are also delivering lectures focused on distance education.

Another challenge faced by VMUROL is the compilation, organization, and eventual delivery of preliminary distance education courses targeted at secondary school students wishing to gain entrance into the University. Once such courses are organized by our Distance Education Center offices located at VMUROL's affiliates, they will be disseminated to other towns and rural territories.

Providing access to technology is another challenge. In this instance, networked computer and language labs will soon be installed at VMUROL's affiliates, that will enable the University to communicate more effectively with its part-time students, as well as provide a more robust platform upon which to deliver and teach the DE course material currently under development.

In order to reduce students' need to pursue their university studies in other Ukrainian cities or abroad is another challenge, VMUROL cooperates with many Ukrainian and foreign educational institutions. In the future, it is anticipated increased inter-institutional cooperation will lead to the creation of a virtual institute or university that will enable Ukrainian and foreign students to earn a certificate or degree without changing their place of residence.

In summary, the author is confident that all Ukraine's state- and non-stateowned higher educational institutions will soon be engaged in hybrid distance education initiatives on varying levels to combine traditional education with the newest technologies available.

International Review of Research in Open and Distance Learning 
Ukraine Open University: Its Prospects in Distance Education Development14

\section{References}

Dovgialo O., Hrytsenko V., Hurdzhy A., Zgurovsky M. (1996). Educational Policies and New Technologies. Proceedings from the 2nd International UNESCO Conference on Education and Informatics, Moscow, Russia.

Corness, P. Haiduk N. (Eds.). (1998). Getting on in English. Lviv, Ukraine: JV BaK

Information About Distance Education in the World and Modern Information Technologies (2000). (Talanchuk, P. Ed.). Kyiv, Ukraine: VMUROL. (in Ukrainian).

Matthews D. (1999). The Origins of Distance Education and its use in the United States. T.H.E. Journal, 27, 2, 54-67.

Osaulenko O. (1999). Statistical Yearbook of Ukraine for 1999. Kyiv: Technica, p. 432 (in Ukrainian).

Shunevych B. (1999). Case Technology of Distance Education. Proceedings of the Conference on Innovative Trends in the Foreign Language Instruction. (p. 55) L'viv, Ukraine: LTA (in Ukrainian).

Shunevych B. (2001). Educational Materials for Foreign Language Distance Learning. Proceedings of the 20th ICDE World Conference on Open and Distance Learning: Learning for the Future: Shaping the Transition. Düsseldorf, Germany, 1-5 April 2001, [Online] http://www.icde.org (in English)

Shunevych B., Kokhan A. (2000). Network Technology of Distance Education. Proceedings of International Conference on Linguistic and Methodological problems of Foreign Languages Instruction. 23-25 Poltava, Ukraine: UMSA (in Ukrainian).

Talanchuk P., Shevtsov A., Bazhan V., and Hemba V. (2001). Creation of Didactic Materials for Distance Form of Education. Kyiv, Ukraine: VMUROL, p. 48 (in Ukrainian).

Talanchuk P., Onkovych H. (2000). Topical Issues of Disabled Student Education.

Kyiv, Ukraine:VMUROL, 384 - 401 (in Ukrainian)

Citation Format

Shunevych, Bohdan (January, 2002) Ukraine Open University: Its Prospects in Distance

Education Development. International Review of Research in Open and Distance Learning: 2, 2.

http://www.icaap.org/iuicode?149.2.2.14

International Review of Research in Open and Distance Learning 